\title{
Medicine Substitution Practices in Social Health Insurance Outpatients of Public Hospital
}

\author{
Dian Medisa ${ }^{1}$, Sulanto Saleh Danu ${ }^{2}$, Rustamaji $^{2}$ \\ Departement of Pharmacy, Islamic University of Indonesia, IndonesiaFaculty of Medicine, Gadjah Mada \\ University, Indonesia
}

\begin{abstract}
Social health insurance program known as Jamkesmas was made by Indonesia's Government to increase the health care accessibility and quality. The generic substitution policy for Jamkesmas patient can give lower prescription cost. But in fact, there was still substitution from generic medicine into brand-name in pharmacy practice. The aim of this research was to know medicines substitution from generic into brandname in social health insurance outpatients of public hospital. This research was an observational-study using prescriptions of social health insurance outpatients and as qualitative data using in-depth interviewed. This study showed that the percentage of medicines substituted by $4.0 \%-26.5 \%$ and the precentage of increased prescriptions cost which substitued from generic into brand name was $0 \%-76.9 \%$. The conclusion was substitution of generic medicine to brand name increased the prescription medicines cost.
\end{abstract}

Keyword: medicines, substitution, outpatient, public hospital, jamkesmas

\section{Introduction}

Every human has rights to access a health care, but infact a lot of people still can't fullfil the rights. In Indonesia, it's happened because of the high healthcare cost, so that the government create a social health insurance program called Jamkesmas (Anonim, 2008). The social health insurance program was created not only to overcome the problem of accessing health care and control the healthcare cost but also to increase the quality of health and medical care by using Indonesia-Case Based Groups, well-known as INA-CBGs. The healthcare cost claimed based on diagnose or case based group. If healthcare costs are higher than the cost of the package in INA-CBG, then the hospital should bear the excess cost (Anonim, 2010).

Appropriaty use, effectivity, safety, affordability, and availability of medicines are the important elements in achieving quality of healthcare (WHO, 1983). Therefor, some policies were made by the government to give the best health services for social health insurance's patients. One of the policies is generic substitution or switching, so that the patient can get medicines as needed and the prescription medicines cost can be lower (Liberman and Roebuck, 2010). In fact, substitution from generic medicines into brand-name still happened in pharmacy practice because of complicated reason. This research was to know the percentage of medicines substitution from generic to brand-name in social health insurance outpatients of public hospital and to know the increased-prescription cost which medicines were switched from generic into brand name.

\section{Material And Methods}

This was an observational study using quantitative and qualitative approach. Quantitative data were collected from prescription of Jamkesmas outpatients, transaction data, price lists of generic medicines by government, and medical records. Otherwise, depth-interviewed to Head of Hospital Pharmacy Departement were used as qualitative data. It was collected after getting the quantitative data.

Percentage of medicines substitution was calculated by deviding the number of medicines substituted by the total number medicines prescribed. In this study, the medicine substitution included substitution from generic into brand name medicines. Otherwise, percentage of increased prescription cost which generic substituted into brand name was calculated by deviding the difference of cost of prescription which generic medicines substituted into brand name and cost of generic prescription medicines by cost of generic prescription medicines.

The sample used was Jamkesmas outpatient prescriptions within January-March 2011. Prescriptions with single diagnosis, including Urinary Tract Infection (UTI), Congestive Heart Failure (CHF), Diabetes Millitus (DM), Hypertension, Low Back Pain (LBP), Stroke, Epilepsy, Vertigo and Migrain. The sample size for each disease was the entire prescriptions with a single diagnosis obtained in the period January-March 2011. 


\section{The Result}

The precentage of medicines substitution in 9 disease was showed on Table 1 below:

Table 1. The precentage of medicines substitution in social health insurance outpatients of

\begin{tabular}{clccc}
\multicolumn{1}{c}{ Public Hospital period January-March 2011. } & $\begin{array}{c}\text { Percentage of } \\
\text { Notal number of } \\
\text { medicines were } \\
\text { prescribed }\end{array}$ & $\begin{array}{c}\text { Nedicines substituted } \\
\text { into brand names } \\
\text { generic medicines } \\
\text { substituted into } \\
\text { brand names } \\
(\%)\end{array}$ \\
\hline 1 & LBP & 466 & 81 & 17.4 \\
2 & Epilepsy & 287 & 49 & 17.1 \\
3 & DM & 199 & 30 & 15.1 \\
4 & UTI & 225 & 9 & 4.0 \\
5 & CHF & 355 & 94 & 26.5 \\
6 & Hypertension & 184 & 23 & 12.5 \\
7 & Migrain & 264 & 24 & 9.1 \\
8 & Stroke & 172 & 19 & 11.0 \\
9 & Vertigo & 130 & 8 & 6.2 \\
\hline
\end{tabular}

The table showed that the precentage of medicines substitution was started from $4.0 \%-26.5 \%$, and the highest precentage was CHF and the lowest was UTI-4.0\%. In CHF disease, there were a lot of substitution from generic into brand name, such digoxin become Fargoxin $®$. Otherwise, the substitution from hyosin bromida to Scopamin ${ }^{\circledR}$ in UTI. The precentage of medicines substitution was also high in LBP-17.4\% and epilepsy-17.1\%. The most frequent substitution in LBP was ketorolac to Dolac®.

The precentage of increased cost of prescription which generic medicines substituted into brand-named was showed on table 2 below:

Tabel 2. Percentage of increased prescription cost which generic substituted into brand name in social health insurance outpatients of Public Hospital

\begin{tabular}{|c|c|c|c|c|c|}
\hline No & Disease & $\begin{array}{c}\text { Number of prescriptions } \\
\text { which generic medicines } \\
\text { substituted into brand } \\
\text { names }\end{array}$ & $\begin{array}{l}\text { Cost of generic prescription } \\
\text { medicines substituted into } \\
\text { brand names } \\
\text { (IDR) }\end{array}$ & $\begin{array}{l}\text { Cost of generic } \\
\text { prescription } \\
\text { medicines } \\
\text { (IDR) }\end{array}$ & $\begin{array}{l}\text { Precentage of } \\
\text { increased cost } \\
(\%)\end{array}$ \\
\hline 2 & Epilepsy & 45 & $2,412,630$ & $1,363,706$ & 76.9 \\
\hline 3 & $\mathrm{DM}$ & 26 & 594,305 & 567,656 & 4.7 \\
\hline 6 & Hypertension & 19 & 475,268 & 449,795 & 5.6 \\
\hline 7 & Migrain & 24 & $1,340,513$ & $1,329,545$ & 0.8 \\
\hline 8 & Stroke & 16 & 277,965 & 264,055 & 5.2 \\
\hline 9 & Vertigo & 7 & 241,910 & 237,341 & 1.9 \\
\hline
\end{tabular}

From the table 2, known that the substitution of generic medicines into brand name medicines cause the increased-prescriptions cost. The highest-increased showed on epilepsy disease, which was reach $76.9 \%$.

\section{Discussion}

The medicines substitution from generic into brand name medicines made by pharmacist to meet the patient's need for medications. Based on the health minister regulations, the substitution can be done on the switching of brand name medicines into generic names, so these medicines more affordable. But in reality, there were still substitution of generic medicines into brand name. From depth-interviewed to Head of Hospital Pharmacy Departement known that it's happened because some of the generic medicines were stock out in hospital pharmacy and others were not available in the market. Many manufacturers not interest in producing generic medicines because it gave small profit. But the patient's medication needs must be meet, so that pharmacist were forced to make substitution. To decrease substitution of generic into brand name, government must ensure the availability of generic medicines on the market through collaboration with the pharmaceutical industry. Beside that, government regulation of generic prescription medicines must be supported by a guarantee bioequivalence between generic and brand name medicines, so generic medicines will result the same clinical effect and safety profile as brand name (Vivian, 2008).

Substitution of generic medicines into brand names would be increasing the cost of prescription, except both of the medicines-generic and brand name have the same price. In fact, most of the medicines with brand 
name was more expensive than generic medicines. It can be seen on table 2 , that the substitution generic medicines into brand name increased about $0 \%-76.9 \%$ of prescription medicines cost. It showed that generic prescribing could result the prescription cost saving. As research from Haaj, et al. (2005) that "although broad substitution of generic drugs would affect only a modest percentage of drug expenditures, it could result in substantial absolute savings". In epilepsy, substitution of generic into brand name medicine didn't caused the increased-prescription cost because generic (ketorolac) and brand name (Dolac $®)$ have the same price. The medicines listed in sosial health insurance formulary are generic names and based on national essential medicines list, so that the medicines have a good quality, safe, effective, and affordable. Generic prescribing or substitution of brand name into generic medicines can reduce the prescription medicines cost. It has been reported by Ping, et al. (2008) that patient could economize the cost of prescribed medications by generic substitution. Therefor, generic substitution is expected to save the expenditure of sosial health insurance patient medication so that does not exceed the cost of INA-CBGs.

\section{Conclusion}

The percentage of generic medicines substituted into brand-name for about $4.0-26.5 \%$ and it had done by pharmacist for met the patient needs. The substitution of generic medicines to brand-named increased prescription medicines cost (0\%-76.9\%). To prevent the substitution of generic into brand-name medicines, hospital pharmacy department must manages the generic drugs availability properly. So does the generic medicines availability on the market must be ensured by government by cooperating with some manufacturers.

\section{Reference}

[1]. Departemen Kesehatan Republik Indonesia, Pedoman Pelaksanaan Jaminan Kesehatan Masyarakat (Jamkesmas), Departemen Kesehatan Republik Indonesia, Jakarta, 2008.

[2]. Kementerian Kesehatan Republik Indonesia, Pedoman Pelaksanaan Jaminan Kesehatan Masyarakat (Jamkesmas), Kementerian Kesehatan Republik Indonesia, Jakarta, 2010

[3]. Haas JS, Phillips KA, Gerstenberger EP, Seger AC, Potential savings from substituting generic drugs for brand-name drugs: medical expenditure panel survey, 1997-2000, Ann Intern Med. Jun (2005); 42(11): 891-7.

[4]. Hafeez, A, Kiani, AG, ud Din, S, Muhammad, W, Butt, K, Shah, Z, Mirza, Z, Prescription and Dispensing Practice in Public Sector Health Facilities in Pakistan: Survey Report, J Park Med Assoc. 2004; 54 (4): 187-191.

[5]. Liberman, JN and Reobuck, MC, Prescription Drug Cost and the Generic Dispensing Ratio, JMCP, September (2010); Vol.16 (7).

[6]. Ping CC, Bahari MB, Hassali MA, A pilot study on generic medicine substitution practices among community pharmacists in the State of Penang, Malaysia, Pharmacoepidemiol Drug Saf. 2008 Jan;17(1):82-9

[7]. Vivian, JC, Generic Substitution Laws, US Pharm, (2008); 33(6)(Generic Drug Review): 30-34.

[8]. WHO, How to Investigate Drug Use in Health Facilities, World Health Organization Action Programme on Essensial Drugs, Geneva, Switzerland, 1983. 